\title{
Manipulacja informacją na rynkach finansowych: przyczynek do analizy na przykładzie rynku kapitałowego w Polsce*
}

Paweł Podolski**

\section{Wstęp}

Problem manipulacji, fałszerstw i oszustw na rynkach wydaje się tak stary, jak sama idea wymiany rynkowej. W toku rozwoju rynków finansowych i instytucji nadzoru finansowego techniki manipulacji przyjmowały coraz bardziej wysublimowaną i trudniejszą do jednoznacznej penalizacji formę. W niniejszej pracy podjęto problem manipulacji ceną instrumentów finansowych za pomocą informacji w ujęciu prawno-ekonomicznym. Celem artykułu jest opisanie i przedstawienie podstawowych charakterystyk zjawiska manipulacji cenami instrumentów finansowych za pomocą informacji. Na podstawie danych Komisji Nadzoru Finansowego (KNF) i Giełdy Papierów Wartościowych (GPW) przeprowadzony został przyczynek do analizy znaczenia jakości informacji finansowej dla efektywności rynku w odniesieniu do najważniejszych źródeł komunikatów wykorzystywanych przez inwestorów (raporty okresowe i bieżące, analizy i rekomendacje analityków, doniesienia medialne czy informacje poufne, plotki i pogłoski). Wiele miejsca poświęcono zdefiniowaniu pojęć informacji i manipulacji ze względu na powszechność ich użycia w różnych dziedzinach, a w konsekwencji wielość współistniejących i nie zawsze poprawnych definicji tych konstruktów.

\section{Pojęcie informacji}

Klasyczna definicja informacji jako redukcji niepewności (Hintikka 1970), a co za tym idzie redukcji ryzyka, w naturalny sposób wskazuje jej istotną rolę w podejmowaniu jakichkolwiek decyzji, w tym decyzji inwestycyjnych. Pojęcie informacji

\footnotetext{
*Publikacja została sfinansowana ze środków Narodowego Centrum Nauki w ramach grantu „Behawioralne i mikrostrukturalne uwarunkowania rynków finansowych i inwestycji alternatywnych" (UMO-2015/17/B/HS4/02708).

** Paweł Podolski - magister, Uniwersytet Ekonomiczny w Krakowie, Wydział Finansów i Prawa, Katedra Rynków Finansowych, podolskp@uek.krakow.pl.
} 
pochodzi od łacińskiego słów informare, które oznacza nadawanie kształtu, formy, oraz informatio, będącego określeniem gotowego już przedstawienia czegoś. Funkcją informacji jest ,zmniejszenie nieokreśloności sytuacji decyzyjnej” (Biela 1976). Desygnat pojęcia informacji pozostaje zatem zawsze w związku z podejmowaniem decyzji.

Pojęcie informacji należy rozważać w kontekście układu komunikacyjnego, którego elementami są: źródło sygnałów (układ nadający informację i układ ją kodujący), kanał komunikacyjny oraz układ odbiorczy, który w sytuacji decyzyjnej może być utożsamiany z decydentem. Sygnał informacyjny, w odróżnieniu od fali nośnej, jest nośnikiem wiadomości.

Informacja może być ujmowana jako statystyka będąca liczbą określającą, ile danych zostało przeniesionych ze źródła do układu odbiorczego w efekcie dostarczenia określonego komunikatu. Podstawą takiego rodzaju obliczeń jest założenie, że dla każdego komunikatu, który może być dostarczony, istnieje określone prawdopodobieństwo jego dostarczenia, na podstawie którego możliwe jest ustalenie ilości danych przeniesionych przez ten komunikat (Coombs, Dawes, Tversky 1977).

Wprowadzenie rozróżnienia między terminami ,informacja”, „,dane” i „wiedza" przypisuje się N.L. Henry'emu (1974). W roku 1987 M. Zeleny (1987) przedstawił koncepcję hierarchii DIKW, obejmującej oprócz danych, informacji i wiedzy także poziom mądrości. DIKW to akronim pochodzący od pierwszych liter angielskich nazw terminów wchodzących w skład hierarchii: data (dane), information (informacja), knowledge (wiedza) i wisdom (mądrość) ${ }^{1}$.

Dane mogą być przez różnych badaczy odmiennie definiowane, np. jako: zestawienie znaków zgodne z zasadami określonej składni; fakty, koncepcje lub wyniki w postaci, która może być komunikowana i interpretowana (Galland 1982); surowe fakty, które mogą być kształtowane i formowane, by stworzyć informacje (Laudon, Laudon 1991). Cechą wspólną większości definicji jest ujmowanie danych jako nieustrukturyzowanych faktów, które mogą zostać przekształcone w informacje.

Za informacje uznaje się bowiem zazwyczaj dane skategoryzowane, skorygowane, skondensowane tak, aby były interpretowalne w określonym kontekście (Probst, Raub, Romhardt 2004). Kwestia odpowiedniego przetworzenia danych, tak aby tworzyły postać użyteczną i posiadającą znaczenie dla podmiotu w konkretnej sytuacji, stanowi kryterium definicyjne większości definicji informacji (Hicks 1993).

Jednak w najbardziej ogólnym ujęciu proponowanym w filozofii informacja jest odwzorowaniem różnorodności cechującej rzeczywistość, obejmującej całe spektrum takich kategorii jak: obiekty, zdarzenia, procesy czy zjawiska (Ursul 1971, Stefanowicz 2013). Informację odnosi się zatem do otoczenia, w którym

\footnotetext{
${ }^{1}$ Ze względu na cel artykułu, którym jest analiza problemu manipulacji kursem instrumentów finansowych za pomocą informacji, szczegółowo omówiony zostanie jedynie poziom danych i informacji. Wiedza może zostać zdefiniowana jako zorganizowany zbiór informacji wraz z regułami ich interpretowania. Mądrość bywa traktowana jako umiejętność praktycznego wykorzystywania posiadanej wiedzy i doświadczenia.
} 
znajduje się odbiorca. Ujęcie informacji w sposób przedstawiony w przytoczonych definicjach wydaje się jednak niewystarczające, gdyż nie pozwala na wywnioskowanie bezpośrednio z definicji sposobu rejestracji i przetwarzania informacji, możliwych do przeprowadzenia operacji czy cech i właściwości analizowanego konstruktu.

Z tego powodu użyteczna wydaje się infologiczna koncepcja informacji przedstawiona przez B. Stefanowicza (2013) na podstawie propozycji B. Sundgrena (1973) i B. Langeforsa (1980). W koncepcji tej informacja jest opisem rzeczywistości (R), który może być traktowany jako model rzeczywistości R w umyśle odbiorcy (U). Model powstaje w wyniku odebrania opisu rzeczywistości R, poddanego analizie, interpretacji oraz ocenie na podstawie dotychczasowej wiedzy i doświadczenia odbiorcy - systemu odniesienia (frame of reference). Opis konkretnego obiektu stanowiącego element rzeczywistości może zostać przedstawiony w formie komunikatu (K) złożonego $\mathrm{z}$ :

1. O - obiektu, który może oznaczać m.in.: dowolny przedmiot materialny, pojęcie, konstrukt teoretyczny, proces czy zdarzenie;

2. $\mathrm{X}$ - cechy, ze względu na którą obiekt $\mathrm{O}$ jest analizowany przez odbiorcę $\mathrm{U}$

3. $x$ - wartości cechy;

4. $\mathrm{t}$ - czasu, w którym obiekt O przyjmuje wartość $x$ cechy X;

5. $\mathrm{v}$ - wektora dodatkowych charakterystyk związanych $\mathrm{z}$ elementami $\mathrm{O}$, $\mathrm{X}, x$ czy t;

w postaci układu:

$$
\mathrm{K}:<\mathrm{O}, \mathrm{X}, x, \mathrm{t}, \mathrm{v}>
$$

Informacja jest więc relacją zdefiniowaną zgodnie z powyższą formułą na elementach komunikatu K. Komunikat, wiążąc przedstawione elementy relacją, nazywaną $\mathrm{w}$ koncepcji infologicznej relacją informacyjną, nadaje im określony sens. Zdefiniowana w ten sposób informacja $I(\mathrm{~K})$, dostarczona przez komunikat $\mathrm{K}$, jest obiektywna, gdyż istnieje niezależnie od odbiorcy. Taka informacja jest określana przez B. Sundgrena (1973) informacją na poziomie datalogicznym, ponieważ można nią operować w sytuacjach, w których nie zachodzi konieczność interpretacji treści komunikatu K. Przykładem takiej sytuacji może być gromadzenie, przechowywanie, przetwarzanie i udostępnianie informacji w systemach statystyki publicznej, zanim zostanie ona zinterpretowana i wykorzystana przez odbiorcę.

W podejmowaniu decyzji ekonomicznych kluczową rolę odgrywa jednak informacja interpretowana przez odbiorcę, decydenta. Aspekt pragmatyczny wymaga zatem uwzględnienia procesu interpretacji, przetworzenia $I(\mathrm{~K})$ przez odbiorcę U. Taką przetworzoną, pragmatyczną informację można oznaczyć jako $I(\mathrm{~K}, \mathrm{U}, \mathrm{Q})$, gdzie $I$ oznacza informację dostarczoną w komunikacie $\mathrm{K}$ i odebraną przez $\mathrm{U}$ 
w określonym kontekście Q. W efekcie informacja $I(\mathrm{~K}, \mathrm{U}, \mathrm{Q})$ staje się subiektywna, zależna od odbiorcy. Dane, aby były użyteczne i miały znaczenie dla podmiotu, nie mogą być bowiem przetwarzane w oderwaniu od bieżącej sytuacji oraz przetwarzającego je podmiotu (Beynon-Davis 1999). Informacja $I(\mathrm{~K}, \mathrm{U}, \mathrm{Q})$ może zostać zatem przedstawiona jako: „treść wiadomości przekazywanej od nadawcy do odbiorcy, wyrażona w odpowiednim języku lub kodzie. Informację można przenosić w czasie (zapamiętywanie) i przestrzeni (przesyłanie, przekazywanie, komunikowanie), powinna porządkować system, do którego się odnosi. Powinna pozwolić odbiorcy na lepsze dostosowanie się do świata zewnętrznego poprzez ukierunkowanie jego zachowań" (Meyer 2006, s. 225-229).

Zacytowana definicja B. Meyer (2006) uwzględnia większość kluczowych własności informacji rozumianej jako treść zawarta w komunikacie $\mathrm{K}$ stanowiącym nośnik informacji (Stefanowicz 2013):

1. Informacja istnieje jedynie jako treść komunikatu.

2. Informacja $I(\mathrm{~K})$ - datalogiczna, obiektywna - istnieje niezależnie od podmiotu odbierającego.

3. Informacja może zawierać opis jedynie części rzeczywistości. Uzyskanie wglądu w szerszy zakres analizowanej rzeczywistości wymaga dostępu do kolejnych informacji. Nie jest możliwe np. kompleksowe zweryfikowanie rzeczywistej sytuacji spółki giełdowej, jeśli do dyspozycji ma się tylko pojedynczą informację prasową na jej temat.

4. W odniesieniu do informacji zachodzi efekt synergii, który polega na tym, że jednoczesne wykorzystanie dwóch lub więcej informacji przyniesie lepsze efekty niż te, które można byłoby uzyskać, gdyby zastosowało się każdą z nich oddzielnie. Efekt jest uwarunkowany dostępem do wyników obserwacji obiektu $\mathrm{O}$ nie tylko z jednej perspektywy, ale z dwóch lub więcej perspektyw. Przykładem może być ocenienie spółki na podstawie informacji prasowej uzupełnionej raportem bieżącym lub raportem agencji ratingowej, wydanymi niezależnie od okoliczności przygotowania notatki prasowej.

5. Informacja o obiekcie $I(\mathrm{~K}, \mathrm{U}, \mathrm{Q})$ jest w procesie przetwarzania łączona Z wcześniej dostępną odbiorcy wiedzą na jego temat. W efekcie dostępu do informacji obraz tego obiektu u odbiorcy ulega zmianie. Ze względu na efekt synergii i różny zakres wcześniejszej wiedzy dostęp do tej samej informacji może u różnych odbiorców wywołać różne zmiany w obrazie obiektu. Inaczej na informację o odnotowaniu strat w bilansie rocznym spółki zareaguje inwestor analizujący raporty kwartalne i półroczne, a inaczej inwestor, który pierwszy raz zapoznaje się z jej sytuacją.

6. Możliwe jest powielanie oraz przenoszenie informacji w czasie (zapamiętywanie) i przestrzeni (przesyłanie, przekazywanie, komunikowanie), co nie powoduje zużywania informacji. W trakcie tych procesów mogą się jednak pojawiać zniekształcenia wywołane różnymi czynnikami 
zakłócającymi (szumami). Na rynku może dochodzić do rozprzestrzeniania się plotek i pogłosek powstających zazwyczaj na podstawie mniej lub bardziej wiarygodnych informacji.

7. Mimo że informacje można przetwarzać - modyfikować komunikaty, nie prowadząc do ich zniszczenia - to możliwe jest, podobnie jak w przypadku powielania i przenoszenia, pojawianie się deformacji i zniekształceń informacji w efekcie inkluzji do komunikatu fałszywych elementów składowych: obiektu, cech, wartości cech, czasu czy wektora. Przykładem może być powstanie zmanipulowanego doniesienia medialnego powstałego w wyniku błędnego przeanalizowania treści raportu bieżącego wydanego przez spółkę.

8. Niejednakowy rozkład informacji w otoczeniu implikuje powstanie asymetrii informacyjnej, której efektem jest nierównomierny dostęp do informacji w przypadku różnych odbiorców. Asymetria informacyjna ma istotne skutki dla funkcjonowania rynków - może prowadzić m.in. do nieefektywnej alokacji zasobów.

Z własnościami informacji związane są przypisywane jej funkcje jako: zasobu, kapitału, towaru, czynnika motywacyjnego czy kulturotwórczego. Niezależnie od jej charakteru i obszaru, którego dotyczy, spełnia określone, podstawowe funkcje, do których zalicza się przede wszystkim odwzorowanie rzeczywistości w wyniku prezentacji obiektów, stanów, procesów czy zdarzeń z przeszłości, teraźniejszości i przyszłości. Redukując stopień nieokreśloności, umożliwia identyfikację i antycypację obiektów $(\mathrm{O})$, a w efekcie - tworzenie i zmianę rzeczywistości (Wierzbicki 1981).

Informacja pełni funkcję czynnika sterującego, umożliwiającego podejmowanie świadomych decyzji. Dostęp do informacji pozwala zidentyfikować i właściwie zdefiniować przestrzeń problemową (Newell, Simon 1972), co ułatwia wybór strategii rozwiązania problemu. Sterująca funkcja informacji jest szczególnie widoczna w sferze gospodarczej, w której dostęp do informacji rzetelnie opisujących rzeczywistość i redukujących niepewność w odniesieniu do podejmowanych działań ma decydujący wpływ na osiągnięty wynik finansowy. Należy jednak podkreślić, że znaczenie ma nie tyle ilość dostępnych informacji, co ich jakość ${ }^{2}$, gdyż nadmiar informacji może prowadzić do przeciążenia zdolności poznawczych decydenta.

\section{Informacja na rynkach finansowych}

Coraz większa złożoność i integracja współczesnych rynków finansowych sprawiają, że szybki dostęp do rzetelnych i prawdziwych danych ma dla inwestorów coraz większe znaczenie. Wymaga to efektywnego identyfikowania, mierzenia

${ }^{2}$ Jakość informacji zostanie zdefiniowana w rozdziale 3 niniejszej pracy. 
i przekazywania informacji o treści ekonomicznej, umożliwiających ocenę i podejmowanie decyzji przez użytkowników tych informacji, co stanowi istotę rachunkowości (American Accounting Association 1966).

Informację finansową można zdefiniować jako ,wgląd w rzeczywistość finansową" (Patterson 2010, s. 168), którą można ujawnić dzięki posiadanym informacjom. Do zaklasyfikowania komunikatu jako informacji, a nie jedynie ciągu danych jego użytkownicy muszą umieć zredukować niepewność i mieć lepsze pole do podejmowania decyzji na podstawie uzyskanego komunikatu. Uzyskanie wglądu w rzeczywistość finansową jest bowiem uwarunkowane jakością informacji, którą posługuje się podmiot.

Informacje o treści ekonomicznej mają wpływ na efektywność podejmowania decyzji gospodarczych, a przy tym mają zarówno empiryczny, jak i społeczny charakter, są więc zatem narażone na szybką dezaktualizację (Stefanowicz 2010), uwarunkowane kontekstem interpretacje, nieścisłości (Krasodomska 2014) oraz manipulacje i fałszerstwa (Komisja Nadzoru Finansowego 2011).

\section{Jakość informacji finansowych}

Jakość informacji bywa definiowana jako zbiór wszystkich jej właściwości, które czynią ją zdolną do zaspokajania stwierdzonych lub domniemywanych potrzeb jej użytkowników (Idzikowska 2002). W szerszym ujęciu jakość informacji może być warunkowana takimi atrybutami jak: dostępność, dokładność, aktualność, kompletność, spójność, odpowiedniość formy prezentacji, obiektywność czy wiarygodność.

Cechą informacji, która w większości analiz była pożądana przez inwestorów, jest przejrzystość określana także jako transparentność (Dziawgo 2011). Według badań prowadzonych przez D. Dziawgo w latach 2009-2010 prawie połowa (48\%) inwestorów indywidualnych deklarowała gotowość zapłacenia dodatkowej premii za przejrzystość dostępnych informacji. Wśród analityków odsetek ten był jeszcze wyższy - gotowość taką deklarowało 9 na 10 analityków. Grupa ta najwyżej oceniała także spółki, które „w uporządkowany sposób prezentują znacznie więcej informacji, niż wynikałoby to tylko z obowiązków informacyjnych" (Tomczuk, Gajda 2013, s. 126).

Forma prezentacji informacji może mieć istotny wpływ na prawdopodobieństwo ich uwzględnienia w podejmowaniu decyzji inwestycyjnych. Wykazano, że publikowane systematycznie sprawozdania finansowe spółek, stanowiące jedno z bardziej wiarygodnych źródeł informacji, wywierają mniejszy wpływ na wycenę akcji spółki niż późniejsze, mniej wiarygodne, rekomendacje czy komentarze medialne, oparte na tych samych danych (Bloomfeld, Libby, Nelson 1998). Wynika to najprawdopodobniej z mało przystępnej dla przeciętnego uczestnika ryn$\mathrm{ku}$ - numerycznej i tabelarycznej - formy prezentacji danych w sprawozdaniach. 
Wykazano bowiem, że inwestorzy, podejmując decyzje, w większym stopniu uwzględniają informacje o charakterze opisowym niż pozbawione komentarza dane statystyczne (Griffin, Tversky 1992). W badaniach prowadzonych przez G. Gigerenzera i U. Hoffrege'a (1995) nad przyswajaniem reguły Bayesa wykazano, że operowanie obrazowymi przedstawieniami prawdopodobieństwa ułatwia osobom badanym poprawne uwzględnianie proporcji podstawowej. Zgodnie z teorią podwójnego kodowania obrazy są przetwarzane szybciej niż dane prezentowane w formie werbalnej (Pavio 1986), co może przyczyniać się do ich częstszego uwzględniania w trakcie podejmowania decyzji inwestycyjnych.

Stwierdzono także, że informacje złożone (zgodne z prawdą) wymagające przeprowadzenia dodatkowych operacji umysłowych są częściej traktowane jako fałszywe niż te same informacje przekazywane w bardziej przystępny sposób (Szyszka 2009). Zjawisko to, określane jako iluzja nieprawdy, może być jedną z przyczyn konserwatyzmu poznawczego wobec wiarygodnych informacji (np. sprawozdań finansowych) i nadmiernej reakcji na informacje mało wiarygodne (np. plotki czy doniesienia medialne). Konserwatyzm poznawczy może być także wynikiem błędu kotwiczenia w odniesieniu do dotychczasowego poziomu notowań. Wpływ konserwatyzmu poznawczego jest szczególnie widoczny w przypadku efektu momentum (Chan, Jegadeesh, Lakonishok 1996). Ponadto inwestorzy zwykle zbyt intensywnie reagują na dane dotyczące poszczególnych spółek i nie doszacowują wartości informacji systemowych - dotyczących kondycji gospodarki (Jegadeesh, Titman 1995). Wydaje się zatem, że zjawisko przeszacowywania wartości informacji dotyczących pojedynczych spółek i niedoszacowania danych systemowych jest przede wszystkim uwarunkowane konserwatyzmem poznawczym wobec sygnałów wysokiej jakości (Bloomfeld, Libby, Nelson 1998).

W kontekście efektywności informacyjnej rynków i podejmowania decyzji inwestycyjnych szczególnie istotny wydaje się problem dostępności informacji. Brak dostępu do informacji, trudności w przekazywaniu informacji, celowe utrzymywanie asymetrii informacyjnej oraz koszty pozyskania informacji stanowią przesłanki niedoskonałości wiedzy posiadanej przez podmioty uczestniczące w wymianie rynkowej (Zielonka 2011). Należy zwrócić uwagę na to, że informacja, która stanowi pewną całość, może być użyteczna dla podmiotu tylko w sytuacji, gdy posiądzie on niezbędny jej zakres. Zdaniem J.E. Stiglitza (2004) może to stanowić przyczynę niewłaściwego działania niektórych mechanizmów rynkowych, np. prawa malejących przychodów. W nurcie badań poświęconych utrudnieniom w dostępie do informacji wyróżnia się zazwyczaj informację:

1. niedoskonałą - gdy przynajmniej jeden z podmiotów nie zna decyzji podjętych przez innych uczestników rynku i w efekcie nie jest w stanie określić swojej sytuacji na rynku;

2. niepewną - gdy podmiot nie może określić rozkładu prawdopodobieństw wystąpienia możliwych rozwiązań; 
3. asymetryczną - gdy każda ze stron transakcji dysponuje inną ilością informacji, co może zostać wykorzystane w celu uzyskania wyższego dochodu;

4. niepełną - gdy uczestnicy wymiany rynkowej nie posiadają zakresu informacji niezbędnego do podjęcia racjonalnych decyzji.

Należy zwrócić uwagę na to, że informacja niepełna może być uważana za informację nieprawdziwą, zmanipulowaną. Przykładem może być nieujawnianie przez spółkę danych, które powinny, zgodnie z obowiązującymi regulacjami prawnymi, zostać zawarte w informacjach przekazywanych inwestorom.

\section{Manipulacja kursem instrumentów finansowych za pomocą informacji}

Manipulacja może być ogólnie rozumiana jako wywieranie na kogoś wpływu i celowe wprowadzanie go w błąd, a także aranżowanie sytuacji zwiększających prawdopodobieństwo podjęcia przez manipulowany podmiot $\mathrm{z}$ góry przewidzianych przez manipulatora działań, zachowań, przyjęcia określonych opinii, poglądów czy postaw (Bańko 2005), które nie muszą i często nie są zgodne z interesem osoby manipulowanej. Celem zastosowania manipulacji, opartej na technikach wpływu, środkach werbalnych i pozawerbalnych, może być również wykorzystanie naturalnie zachodzącego zjawiska, procesu czy sytuacji w sposób niezgodny z ich pierwotnym, społecznie zdefiniowanym celem. Generalnie manipulacja oznacza wyzyskanie zaufania lub niewiedzy podmiotu w celu zdobycia kontroli nad jego zachowaniem i osiągnięcia w związku z tym korzyści przez manipulatora (Martysz 2015).

Manipulacje na rynku finansowym można ogólnie zdefiniować jako „wywieranie wpływu na osobę lub grupę osób w wyniku oddziaływania informacjami po to, by podmiot manipulacji, nieświadomy genezy całego procesu, formalnie z własnej woli realizował zamierzone cele podmiotu dopuszczającego się manipulacji” (Stokłosa, Syp 2017, s. 11). Celem manipulacji na rynku finansowym jest zazwyczaj osiągnięcie korzyści poprzez wywołanie zmiany ceny instrumentu finansowego w wyniku wprowadzenia inwestorów w błąd.

Manipulacja może wykorzystywać komunikaty werbalne (rozpowszechnianie fałszywych informacji) lub niewerbalne formy przekazu (składanie zleceń czy zawieranie transakcji). W obowiązującym od 3 lipca 2016 roku rozporządzeniu Parlamentu Europejskiego i Rady (UE) nr 596/2014 z dnia 16 kwietnia 2014 r. w sprawie nadużyć na rynku, określanym jako Market Abuse Regulation (MAR), wymieniony jest katalog działań uznawanych za manipulacje:

1. „zawieranie transakcji, składanie zleceń lub inne zachowania, które:

a) wprowadzają lub mogą wprowadzać w błąd co do podaży lub popytu na instrument finansowy, powiązany kontrakt towarowy na rynku 
kasowym lub sprzedawany na aukcji produkt oparty na uprawnieniach do emisji, lub co do ich ceny; lub

b) utrzymują albo mogą utrzymywać cenę jednego lub kilku instrumentów finansowych, powiązanego kontraktu towarowego na rynku kasowym lub sprzedawanego na aukcji produktu opartego na uprawnieniach do emisji na nienaturalnym lub sztucznym poziomie;

2. zawieranie transakcji, składanie zleceń lub inne działania lub zachowania wpływające albo mogące wpływać na cenę jednego lub kilku instrumentów finansowych, powiązanego kontraktu towarowego na rynku kasowym lub sprzedawanego na aukcji produktu opartego na uprawnieniach do emisji, związane z użyciem fikcyjnych narzędzi lub innych form wprowadzania w błąd lub podstępu;

3. rozpowszechnianie za pośrednictwem mediów, w tym internetu, lub przy użyciu innych środków, informacji, które wprowadzają lub mogą wprowadzać w błąd co do podaży lub popytu na instrument finansowy, powiązany kontrakt towarowy na rynku kasowym lub sprzedawany na aukcji produkt oparty na uprawnieniach do emisji, lub co do ich ceny, lub zapewniają utrzymanie się lub mogą zapewnić utrzymanie się ceny jednego lub kilku instrumentów finansowych, powiązanego kontraktu towarowego na rynku kasowym lub sprzedawanego na aukcji produktu opartego na uprawnieniach do emisji na nienaturalnym lub sztucznym poziomie, w tym rozpowszechnianie plotek, w przypadku gdy osoba rozpowszechniająca te informacje wiedziała lub powinna była wiedzieć, że informacje te były fałszywe lub wprowadzające w błąd;

4. przekazywanie fałszywych lub wprowadzających w błąd informacji, lub dostarczanie fałszywych lub wprowadzających w błąd danych dotyczących wskaźnika referencyjnego, jeżeli osoba przekazująca informacje lub dostarczająca dane wiedziała lub powinna była wiedzieć, że są one fałszywe i wprowadzające w błąd, lub każde inne zachowanie stanowiące manipulowanie obliczaniem wskaźnika referencyjnego".

Rozporządzenie MAR stanowi pierwszy instrument prawny na szczeblu Unii Europejskiej ujednolicający prawodawstwa krajowe państw członkowskich w zakresie tzw. nadużyć na rynku. W związku z tym uchylone zostały m.in. oddziały: 2, 3, $4 \mathrm{w}$ rozdziale $2 \mathrm{w}$ dziale II ustawy z dnia 29 lipca 2005 r. o obrocie instrumentami finansowymi (Dz.U. z 2005 r. Nr 183, poz. 1538), których zakres tematyczny był tożsamy z MAR. Zgodnie z uchylonym art. 39 formą manipulacji było „rozpowszechnianie fałszywych lub nierzetelnych informacji albo pogłosek, które wprowadzają lub mogą wprowadzać w błąd w zakresie instrumentów finansowych", a zgodnie z MAR manipulację stanowi rozpowszechnianie za pośrednictwem mediów, w tym internetu, lub przy użyciu innych środków każdego rodzaju informacji, które „wprowadzają lub mogą wprowadzać w błąd co do podaży lub popytu". 
Za formę manipulacji uznaje się zatem m.in. przekazywanie informacji nieprawdziwej lub niepełnej, kształtowanie przekazu w sposób utrudniający poznanie na jego podstawie rzeczywistości lub czyniący informację nierzetelną czy tworzenie szumu informacyjnego. Manipulacja instrumentami finansowymi za pomocą informacji może następować z wykorzystaniem wszelkich dostępnych inwestorom komunikatów: od sprawozdań finansowych, przez analizy i rekomendacje (Barber i in. 2003), po doniesienia medialne (Mullainathan, Shleifer 2005) oraz plotki i pogłoski (DiFonzo, Bordia 1997).

W dalszej części pracy przedstawiono charakterystyki podstawowych kategorii źródeł komunikatów docierających do inwestorów, ze szczególnym uwzględnieniem analiz dotyczących jakości i podatności na manipulację informacji przedstawianych w tych źródłach. Na podstawie wykazu kar nałożonych przez Komisję Nadzoru Finansowego w związku z naruszeniem art. 39 i art. 42 ustawy z dnia 29 lipca 2005 r. o obrocie instrumentami finansowymi (Dz.U. z 2005 r. Nr 183, poz. 1538) przedstawiono przykłady analiz zależności między rozpowszechnianiem fałszywych lub nierzetelnych informacji w okresie hossy poprzedzającej kryzys i kryzysu 2007-2009 a kształtowaniem się wskaźników giełdowych wybranych spółek, których akcje stały się przedmiotem manipulacji.

\section{Raporty okresowe i bieżące}

Raporty roczne są jednymi z najistotniejszych źródeł informacji o wynikach spółki. W skład raportu będącego informacją długoterminową i złożoną wchodzą wyrażone w mierniku pieniężnym informacje finansowe, a także informacje niefinansowe stanowiące uzupełnienie, rozwinięcie lub ujęcie w inny sposób informacji wyrażonych w wartościach liczbowych (Krasodomska 2014). Informacje finansowe mają przede wszystkim charakter retrospektywny - dostarczają historycznych danych na temat funkcjonowania przedsiębiorstwa. Bardziej prospektywne są informacje niefinansowe, stanowiące bardzo zróżnicowaną grupę danych.

Obowiązki informacyjne spółek giełdowych, do których można zaliczyć m.in. publikowanie raportów okresowych czy raportów bieżących, należą do podstawowych narzędzi kształtowania relacji inwestorskich (Łukasik 2013). Właściwe prowadzenie przez spółkę relacji inwestorskich jest związane ze wzrostem zaufania do spółki, poprawą jej wizerunku wśród interesariuszy, wzrostem płynności akcji czy obniżeniem kosztów pozyskiwania kapitału na rynku. Błędnie rozumiane kształtowanie relacji inwestorskich może skłaniać niektóre zarządy spółek do podporządkowywania polityki informacyjnej celom marketingowym, co może się przyczynić do publikowania nierzetelnych danych zestawianych w sposób stronniczy lub uniemożliwiający łatwe dokonywanie porównań w celu manipulowania osiąganymi przez przedsiębiorstwo wynikami.

Ze względu na brak obowiązkowego audytu i mniejszy stopień sformalizowania informacje niefinansowe $\mathrm{z}$ większym prawdopodobieństwem niż informacje 
finansowe mogą stać się przedmiotem tego rodzaju działań. Informacje niefinansowe mogą dotyczyć takich obszarów działalności przedsiębiorstw jak zewnętrzne warunki działania, działalność operacyjna, przewidywany rozwój, akcjonariat i akcje, ład korporacyjny czy społeczna odpowiedzialność, jednak największe ryzyko manipulacji zachodzi w przypadku informacji na temat rodzajów ryzyka, na jakie narażona jest spółka oraz strategii zarządzania ryzykiem (Mikołajek-Gocejna 2008), a także informacji odnoszących się do przewidywanego rozwoju (Krasodomska 2014). Wydaje się, że jest to uwarunkowane z jednej strony trudnością przewidywania $\mathrm{w}$ zmiennym otoczeniu mikro- i makroekonomicznym, a z drugiej strony nadmiernym optymizmem, nie zawsze mającym podstawy w sytuacji finansowej. Na rozbieżności między wnioskami płynącymi $\mathrm{z}$ informacji prezentowanych $\mathrm{w}$ sprawozdaniu finansowym i sekcji opisowych sprawozdania rocznego zwracali uwagę P. Balata i G. Breton (2005). Problematyka przewidywanego rozwoju jest także zdaniem inwestorów prezentowana w najmniej zrozumiały i przystępny sposób w porównaniu z pozostałymi informacjami niefinansowymi (Krasodomska 2014).

Przykładem manipulacji mogą być komunikaty wydawane przez prezesa zarządu spółki Bioton SA, który bezpodstawnie przekazywał do wiadomości publicznej znacznie zawyżone wartości planowanych przychodów przedsiębiorstwa (Kazimierczak 2009). Komisja Nadzoru Finansowego nałożyła na prezesa zarządu karę pieniężną w wysokości 100 tys. zł za „rozpowszechnianie w okresie luty-listopad 2007 r. nierzetelnych, wprowadzających w błąd inwestorów informacji na temat rozwoju spółki Bioton SA, oczekiwanych wyników finansowych i planów ekspansji zagranicznej, które nie znajdowały odzwierciedlenia w następujących po nich wydarzeniach i rzeczywiście osiąganych przez spółkę wynikach finansowych" (Komisja Nadzoru Finansowego 2009). Był to pierwszy przypadek ukarania prezesa zarządu za manipulację informacją.

O wadze problemu przestrzegania przez spółki obowiązków informacyjnych może świadczyć to, że w związku ze sprawą samych tylko opcji walutowych KNF do połowy 2010 r. nałożyła na 12 spółek kary pieniężne o łącznej wysokości ponad 1,5 mln zł. Ukarane spółki nie przekazywały bowiem do wiadomości publicznej we wskazanych w ustawie terminach poufnych informacji o zawieraniu walutowych transakcji pochodnych, które mogły mieć istotny wpływ na osiągane przez nie wyniki finansowe. Straty związane z tego typu transakcjami i wynikającymi z nich spadkami wartości rynkowej firm szacuje się na setki milionów złotych (Komisja Nadzoru Finansowego 2018).

\section{Analizy i rekomendacje analityków}

Wydaje się, że szczególne znaczenie dla funkcjonowania rynku mają rekomendacje i analizy, ponieważ rynek silnie reaguje na ich publikacje (Jegadeesh i in. 2004). Może być to uwarunkowane m.in. przekonaniem inwestorów o tym, że 
są one wydawane, przynajmniej w pewnej mierze, na podstawie informacji niepublicznych (Corgnet, Kujal, Porter 2010). Wykazano, że szczególną rolę mogą odgrywać analizy dotyczące perspektyw rozwoju odnoszące się do spółek mniej znanych, w przypadku których przeciętny inwestor musiałby ponieść ponadnormatywne koszty, aby uzyskać informacje pozwalające na podjęcie racjonalnej decyzji (Blasco, Corredor 2016).

Niektóre analizy i rekomendacje analityków mogą jednak zawierać informacje fałszywe, sprzyjające wzrostowi rozbieżności między ceną waloru a wartością fundamentalną (Lim 2001). Do zniekształceń prognoz może dochodzić $\mathrm{m}$.in. na skutek popełniania systematycznych błędów w ocenie sygnałów analizy technicznej - ulegania inklinacjom poznawczym oraz przejawiania nadmiernego optymizmu. Istotną rolę odgrywają także zachowania stadnych oraz uleganie informacyjnemu i normatywnemu wpływowi społecznemu przez autorów analiz i rekomendacji (Lee, Lee 2015).

Dowodem potwierdzającym ograniczoną trafność prognoz analityków mogą być wyniki analiz B. Barbera, R. Lehavy'ego, M. McNicholsa i B. Truemana (2003), którzy wykazali, że w latach 1986-1996 oraz 1996-1999 utrzymywanie portfeli zgodnie z zaleceniami analityków nie pozwoliłoby na uzyskanie dodatniej stopy zwrotu (przy uwzględnieniu kosztów transakcyjnych). W czasie narastania i pęknięcia bańki (dot-com bubble) w latach 2000-2001 inwestowanie zgodnie z zaleceniami analityków przyczyniłoby się nawet do odnotowania wysokich strat przez inwestorów. Wykazany przez cytowanych badaczy fakt, że kupowanie w okresie dot-com bubble akcji rekomendowanych do sprzedaży pozwoliłoby na uzyskanie ponadprzeciętnych zysków zdaje się potwierdzać to, że prognozy dostarczane przez analityków mogą zawierać fałszywe informacje.

Przykładem manipulacji jest analiza z 24 listopada 2008 r. przygotowana przez UniCredit CAIB Securities UK Ltd., w której akcje spółki Lotos SA bezpodstawnie wyceniono na $0 \mathrm{zł}$, gdyż, jak podano w uzasadnieniu, ,grupa Lotos chyli się ku upadkowi i istnieje ponad 50-procentowe prawdopodobieństwo, że może nie przetrwać w obecnej strukturze" (Iwaniuk 2010). W efekcie akcje Lotosu straciły prawie $6 \%$, a handel nimi został nawet na pewien czas zawieszony. W dniu 18 lutego 2011 r. KNF ukarała grzywną w wysokości 500 tys. zł UniCredit CAIB Securities UK Ltd. w związku z wydaniem rekomendacji bez zachowania należytej staranności i bez zapewnienia rzetelności (Komisja Nadzoru Finansowego 2018). Na wykresie 1 wyraźnie widoczna jest zależność między opublikowaniem rekomendacji 24 listopada 2008 r. a notowaniami spółki Lotos SA w dniach 24 i 25 listopada 2008 r. - zamknięcie nastąpiło po cenie znacząco niższej niż otwarcie, a w dniu publikacji analizy wolumen obrotu wzrósł ponad 10-krotnie, do 2619539 w porównaniu do 237746 z dnia poprzedniego. Sytuacja taka mogła, na podstawie analizy technicznej, być dla inwestorów zapowiedzią dalszych silnych i gwałtownych spadków. 
Wykres 1. Zmiany wolumenu, kursu otwarcia i zamknięcia akcji spółki Lotos SA w związku z publikacją nierzetelnej rekomendacji 24 listopada $2008 \mathrm{r}$.

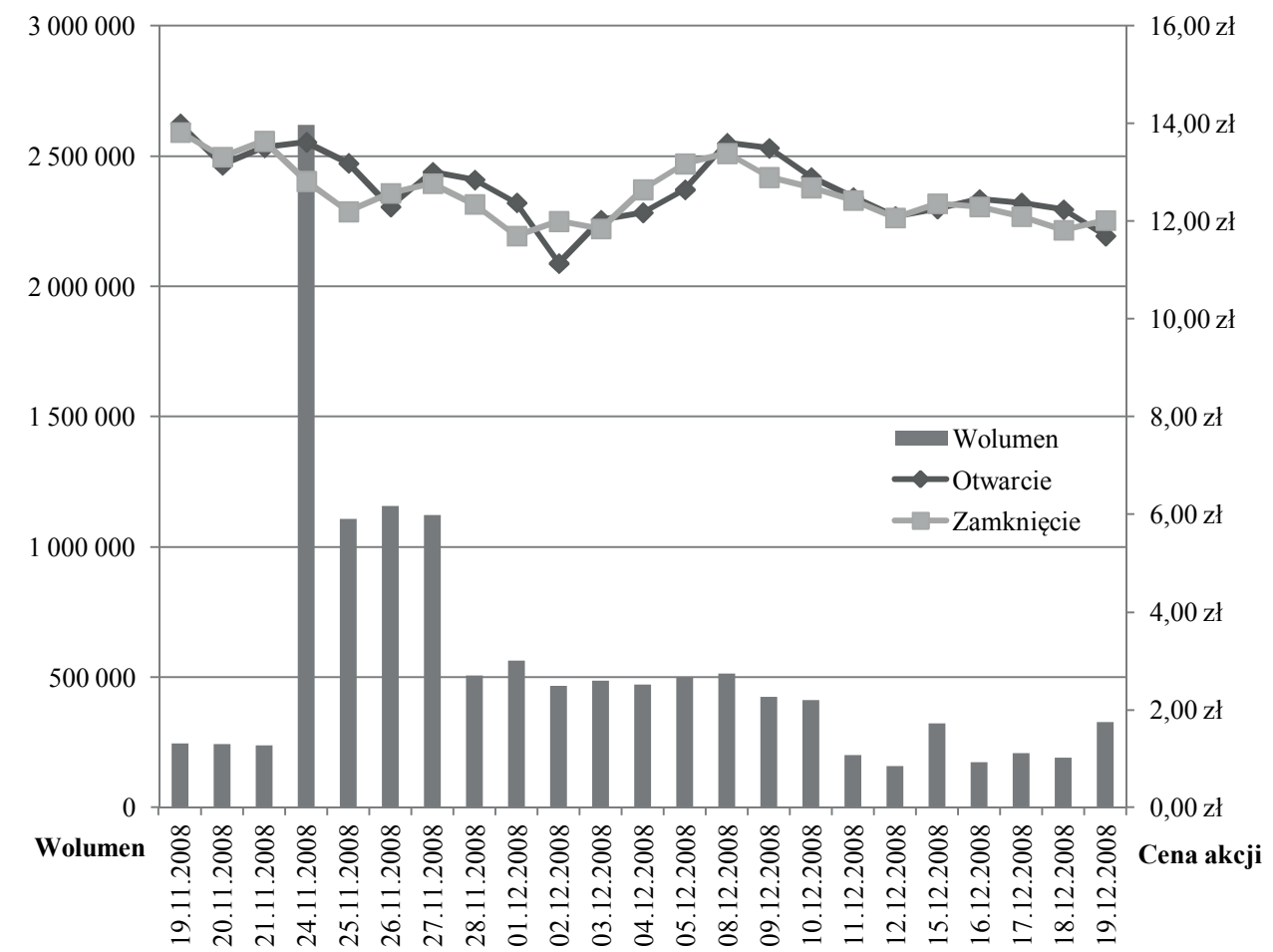

Źródło: opracowanie własne na podstawie danych serwisu GPW.

\section{Informacje poufne, plotki i pogłoski}

Informacje przekazywane $\mathrm{w}$ zamkniętym gronie, $\mathrm{w}$ tym plotki, mogą być podstawą decyzji inwestycyjnych zarówno inwestorów prywatnych, jak i instytucjonalnych (Fung, Hsieh 1999). Wskazuje się bowiem, że jedynie ograniczona część zmienności stóp zwrotu akcji może zostać wyjaśniona za pomocą dostępnych publicznie informacji (Lorie, Dodd, Kimpton 1985; Cutler, Poterba, Summers 1989).

Odmianą komunikacji bezpośredniej jest plotka, definiowana jako informacja rozpowszechniana stopniowo, w wybranym gronie, o niezweryfikowanej prawdziwości (Rosnow 1991). Plotki bywają przekształcane w niemal pewne wiadomości oraz zniekształcane przez przekazujące je osoby zgodnie z ich wcześniejszymi przekonaniami (Warneryd 2001).

Mimo że tylko około połowa plotek rozpowszechnianych na rynku znajduje potwierdzenie (Pound, Zeckhauser 1990), wywołują one takie same zmiany cen jak potwierdzone informacje. Funkcją plotek jest porządkowanie lub upraszczanie złożonej struktury rynku za pomocą tworzenia związków przyczynowo-skutkowych 
pomiędzy jego elementami, które nie muszą być ze sobą związane. Tworzenie tego typu związków czy dobrych scenariuszy (Tversky, Kahneman 1983) może istotnie modyfikować prognozy i oszacowanie prawdopodobieństwa (Andreassen, Krauss 1990). Eksperymentalnie wykazano, że plotki są traktowane przez inwestorów jak sprawdzone informacje i mogą stanowić podstawę podejmowania decyzji inwestycyjnych mimo świadomości, że informacje w nich zawarte są fałszywe (DiFonzo, Bordia 1997). Plotki, nawet te całkowicie nieprawdziwe, mogą wywoływać krótkoterminowy efekt momentum i wzbudzać zachowania stadne, a tym samym - przyczyniać się do narastania i pękania baniek spekulacyjnych.

Przykładem może być „,rozpowszechnianie za pomocą środków masowego przekazu, w tym internetu, fałszywych i nierzetelnych informacji na temat spółki” Polna SA przez jednego z inwestorów (Komisja Nadzoru Finansowego 2007). Inwestor po przekroczeniu 5-procentowego progu posiadania akcji poinformował w styczniu o zamiarze przekroczenia progu $10 \% \mathrm{w}$ ciągu najbliższego roku oraz ogłoszenia wezwania na pozostałe akcje (Roguski 2006a). Ponadto zaczął rozpowszechniać pozytywne prognozy i wyceny spółki na podstawie informacji jakoby pozyskanych od zarządu w trakcie rozmów osobistych lub telefonicznych (czemu zarząd spółki jednoznacznie zaprzeczył) (Roguski 2006b). W efekcie kurs akcji wzrósł z 6,85 zł w dniu 12 stycznia 2006 do 11,90 zł w dniu 31 stycznia 2006 (Roguski 2006a), a wolumen obrotu wzrósł w tych dniach z 800 do 15282 akcji. Zmiany wolumenu i kursu akcji spółki Polna SA w związku z rozpowszechnianiem fałszywych informacji zostały przedstawione na wykresie 2 . W lutym 2007 r. KNF nałożyła na inwestora karę w wysokości 100000 zł. Była to pierwsza w historii sankcja nałożona przez komisję na osobę fizyczną za manipulację informacją (Komisja Nadzoru Finansowego 2007).

Wykres 2. Zmiany wolumenu i kursu akcji spółki Polna SA w związku z rozpowszechnianiem fałszywych informacji w styczniu 2006 r.

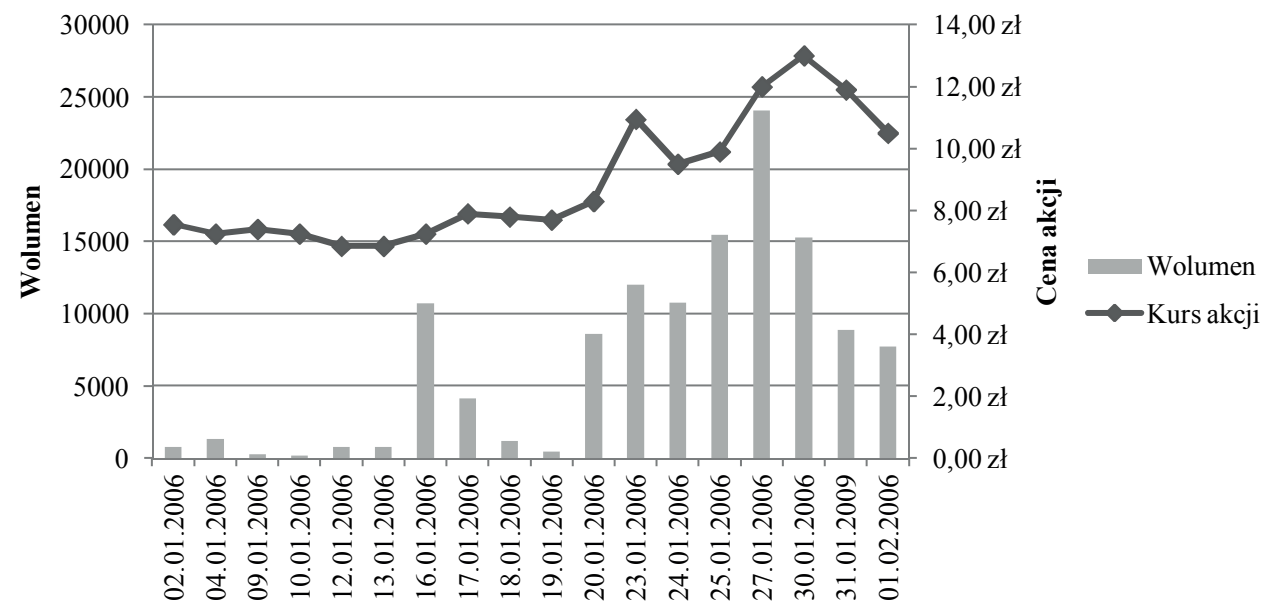

Źródło: opracowanie własne na podstawie danych serwisu GPW. 


\section{Doniesienia medialne i komunikaty spółek}

Doniesienia medialne są obok raportów finansowych spółek, rekomendacji i prognoz analityków oraz bezpośredniej komunikacji międzyludzkiej głównym źródłem informacji dla inwestorów i mogą mieć istotny wpływ na kształtowanie się cen na rynku. Wykazano, że dzięki analizie nastrojów rynkowych wyłaniających się z tekstów publikowanych przez Reutersa możliwe jest lepsze wyjaśnienie bieżącej sytuacji i precyzyjniejsze prognozowanie zmian na rynku niż w przypadku wzięcia pod uwagę czynników makroekonomicznych (Uhl 2014).

Doniesienia medialne są jednak przede wszystkim krótkoterminowym źródłem informacji. W środkach masowego przekazu, umożliwiających szybki obieg informacji, rozpowszechniane mogą być zarówno informacje prawdziwe, jak i zasłyszane plotki czy treści mocno zniekształcone. S. Mullainathan i A. Shleifer (2005) wyróżniają dwa główne rodzaje zniekształceń: kontekst ideologiczny oraz przerysowanie, polegające na nadawaniu przedstawianej informacji nadmiernego znaczenia i mogące sprzyjać popełnieniu przez inwestorów błędu dostępności. Z przerysowywaniem wiąże się także obecna w mediach tendencja do wybiórczego prezentowania jedynie nadzwyczajnych informacji, dotyczących niezwykłych wzrostów lub spadków notowań. Przeciętne spółki rzadko bywają przedmiotem uwagi mediów, w związku z czym przyciągają mniejszą uwagę potencjalnych inwestorów, mimo że mogą stanowić okazję inwestycyjną.

Należy zwrócić uwagę na to, że zdecydowana większość przypadków manipulacji informacją, które zostały wykryte i sankcjonowane przez KNF w okresie od 2006 r. do stycznia 2018 r. miała miejsce w latach 2007-2009 (Komisja Nadzoru Finansowego 2018), a więc w okresie kryzysu finansowego. Wydaje się, że tendencja ta wpisuje się w model zaproponowany przez H. Minsky'ego (1982). Zmanipulowane lub przerysowane informacje przekazane w mediach mogą wywoływać u wielu odbiorców jednocześnie takie same zniekształcenia w postrzeganiu rzeczywistości na rynku, co może być przyczyną euforii na rynku, overtradingu związanego z zachowaniami stadnymi i procesami follow-the-leader, świadczącymi o powstaniu bańki spekulacyjnej. Zdaniem A. Szyszki (2013) sposób przedstawiania oraz doboru informacji przez media mógł być jedną z przyczyn boomu internetowego (dot-com bubble) w latach 2000-2001.

Odrębnym problemem są przekazywane za pośrednictwem mediów do wiadomości publicznej komunikaty członków organów i pracowników spółek. Podobnie jak w przypadku raportów okresowych i bieżących, niewłaściwie pojęta troska o relacje inwestorskie może doprowadzić do podporządkowywania polityki informacyjnej celom marketingowym i skutkować rozpowszechnianiem nie w pełni zgodnych z prawdą informacji. Przykładem może być manipulacja informacją o transakcjach opcyjnych przez prezesa Polskiego Koncernu Mięsnego Duda SA. Prezes zapewniał w mediach, że spółka nie zawierała transakcji 
spekulacyjnych i że nie było ryzyka dla wyniku finansowego (Zatoński 2010). Okazało się to nieprawdą, a w wyniku m.in. strat spowodowanych zastosowaną strategią opcyjną konieczne było wszczęcie wobec spółki postępowania naprawczego.

\section{Podsumowanie}

Z prowadzonych systematycznie ogólnopolskich badań inwestorów wynika, że przestępstwa na rynku kapitałowym są postrzegane jako istotna słabość polskiego rynku (Stowarzyszenie Inwestorów Indywidualnych 2016). Manipulacje informacyjne, w przeciwieństwie do manipulacji transakcyjnych ${ }^{2}$, przysparzają zdecydowanie mniej trudności interpretacyjnych, jeśli chodzi o penalizację poszczególnych technik czy działań. Rozpowszechnianie jakichkolwiek informacji, które wprowadzają lub mogą wprowadzać w błąd co do podaży lub popytu na instrument finansowy, negatywnie wpływa na efektywność rynku. Konieczne jest zatem podejmowanie wszelkich możliwych działań w celu ochrony przed manipulacjami i wykorzystywaniem informacji poufnych. Najbardziej efektywne wydaje się wdrożenie systemowego podejścia do ochrony rynku przed manipulacjami instrumentami finansowymi.

Zarówno w przypadku manipulacji informacyjnych, jak i transakcyjnych pierwszym ogniwem systemu, które styka się z manipulacją, jest inwestor, gdyż to właśnie na podejmowane przez inwestora decyzje usiłuje wpłynąć manipulator, aby uzyskać korzyść. Zalecane byłoby zatem prowadzenie kampanii informacyjnych na większą niż dotychczas skalę, których celem byłoby informowanie o tym zjawisku oraz uświadamianie możliwego wpływu fałszywych, wprowadzających w błąd lub nierzetelnych informacji pochodzących z różnych źródeł na decyzje inwestycyjne, a co za tym idzie - na efektywność funkcjonowania rynku. Wydaje się, że realizacji jednego z głównych zadań instytucji regulujących i nadzorujących rynek, jakim jest nadzór nad przestrzeganiem obowiązującego prawa, w tym norm prawnych dotyczących informacji na rynkach finansowych, sprzyjałoby zaktywizowanie wszystkich uczestników wymiany rynkowej do zgłaszania zauważonych nieprawidłowości w funkcjonowaniu działających na rynku podmiotów. Działania podejmowane przez KNF w tym zakresie należy ocenić raczej jako niewystarczające. Przykładem może być oferowany petentom sposób zgłaszania dostrzeżonych nieprawidłowości na stronie internetowej www.knf.gov.pl, który wydaje się mało intuicyjny i czasochłonny w obsłudze, zwłaszcza dla mniej doświadczonych inwestorów. Godnym uwagi rozwiązaniem byłoby np. wprowadzenie systemu eksperckiego (ekspertowego) umożliwiającego zgłaszającemu

\footnotetext{
${ }^{2}$ Manipulacja transakcyjna polega na wprowadzaniu w błąd innych uczestników rynku w wyniku podejmowanej aktywności rynkowej, czego przykładem może być celowe wpływanie na kształtowanie się ceny instrumentu finansowego poprzez składanie ofert lub zawieranie transakcji.
} 
wstępną weryfikację i klasyfikację zgłaszanego problemu wraz z otrzymaniem informacji zwrotnej.

Kolejnym ogniwem systemu powinny się stać wszystkie instytucje będące uczestnikami rynku - emitenci, instytucje obrotu instrumentami finansowymi, pośrednicy finansowi, a także przedsiębiorstwa $\mathrm{z}$ branży medialnej. Określony przez prawodawcę zakres danych niezbędny do ochrony rynku przed manipulacjami instrumentami finansowymi mógłby być przekazywany i na bieżąco analizowany przez program komputerowy zbliżony do wdrożonej w 2009 r. przez SEC (United States Securities and Exchange Commission) aplikacji do wyszukiwania korelacji pomiędzy transakcjami giełdowymi a pojawiającymi się w mediach informacjami.

Ostatnim ogniwem omawianego podejścia powinien być system prawnej ochrony przed manipulacjami instrumentami finansowymi składający się z wzajemnie uzupełniających się komponentów ochrony karnoprawnej, cywilnoprawnej i administracyjnej, w którym wielkość sankcji byłaby adekwatna do korzyści czerpanych z niezgodnych z prawem działan oraz wielkości szkód powstałych $\mathrm{w}$ funkcjonowaniu rynku w wyniku takich działań; chodzi przede wszystkim o utratę zaufania inwestorów. Dopełnieniem systemu prawnego powinny być efektywnie funkcjonujące wymiar sprawiedliwości i organy ścigania. Warto zwrócić uwagę na to, że z art. 311 ustawy z dnia 6 czerwca 1997 r. - Kodeks karny (fałszowanie informacji w obrocie papierami wartościowymi) w okresie od 2006 do 2016 roku wszczętych zostało 13 postępowań, z czego stwierdzono tylko 4 przestępstwa (Statystyka Policja 2019).

$\mathrm{W}$ niniejszej pracy opisano i przedstawiono podstawowe charakterystyki zjawiska manipulacji cenami instrumentów finansowych za pomocą informacji. Na podstawie zaprezentowanych przykładów analiz zależności między rozpowszechnianiem fałszywych lub nierzetelnych informacji w okresie hossy poprzedzającej kryzys i w czasie kryzysu 2007-2009 a kształtowaniem się wskaźników giełdowych wybranych spółek można stwierdzić, że - niezależnie od źródła komunikatu - w wyniku manipulacji rynek przestaje być efektywny i mogą zostać zaburzone jego podstawowe funkcje: mobilizacja i alokacja kapitału, obrót pieniężny, barometr koniunktury, a przede wszystkim funkcja wyceny kapitału i ryzyka.

\section{Bibliografia}

American Accounting Association (1966), A Statement of Basic Accounting Theory, Evanston.

Andreassen P.B., Krauss S.J. (1990), Judgmental extrapolation and the salience of change, „Journal of Forecasting”, nr 9, s. 347-372.

Balata P., Breton G. (2005), Narratives vs numbers in the annual report: Are they giving the same message to the investors?, „Review of Accounting \& Finance", nr 4 (2), s. 5-14. 
Bańko M. (2005), Wielki słownik wyrazów obcych, Wydawnictwo Naukowe PWN, Warszawa.

Barber B., Lehavy R., McNichols M., Treuman B. (2003), Ressessing the returns to analysts 'stock Recommendations, „Financial Analysts'Journal”, nr 59 (2), s. $16-18$.

Beynon-Davis P. (1999), Inżynieria systemów informacyjnych, WNT, Warszawa. Biela A. (1976), Informacja a decyzja, PWN, Warszawa.

Blasco N., Corredor P. (2016), When and where are informed traders? What is their relationship with analysts in the price discovery process?, „Journal of Behavioral Finance", nr 17 (4), s. 352-364.

Bloomfeld R., Libby R., Nelson M. (1998), Underreactions and overreactions and moderated confidence, ,Journal of Financial Markets”, nr 3, s. 113-137.

Chan L., Jegadeesh N., Lakonishok J. (1996), Momentum strategies, „Journal of Finance", nr 51, s. 16781-1713.

Coombs C.H., Dawes R.M., Tversky A. (1977), Wprowadzenie do psychologii matematycznej, PWN, Warszawa.

Corgnet B., Kujal P., Porter D. (2010), The effect of reliability, content and timing of public announcements on asset trading behavior, „Journal of Economic Behavior \& Organization", nr 76 (2), s. 254-266.

Cutler D.M., Poterba J., Summers L.H. (1989), What moves stock prices?, „Journal of Portfolio Management", nr 15 (3), s. 4-12.

DiFonzo N., Bordia P. (1997), Rumor and prediction: Making sense (but losing dollars) in the stock market, „Organizational Behavior and Human Decision Processes", nr 71 (3), s. 329-353.

Dziawgo D. (2011), Relacje inwestorskie. Ewolucja - funkcjonowanie - wyzwania, Wydawnictwo Naukowe PWN, Warszawa.

Fung W., Hsieh D.A. (1999), A primer on hedge funds, „Journal of Empirical Finance", nr 6, s. 309-331.

Galland F.J. (1982), Dictionary of computing, John Wiley \& Sons, Chichester.

Griffin D., Tversky A. (1992), The weighing of evidence and the determinants of overconfidence, „Cognitive Psychology”, nr 24, s. 411-435.

Henry N.L. (1974), Knowledge management: A new concern for public administration, „Public Administration Review”, nr 34 (3), s. 189-196.

Hicks J.O. (1993), Management information systems: A user perspective, West Publishing, Minneapolis.

Hintikka J. (1970), On semantic information [w:] Information and Inference, Hintikka J., Suppes P. (red.), Reidel Publishing, Dordrecht.

Hoffrege U., Gigerenzer G. (1995), How to improve Bayesian reasoning without instruction: Frequency formats, „Psychological Review”, nr 102 (4), s. 684-704.

Idzikowska G. (2002), Wiarygodność danych a bezpieczeństwo zasobów $w$ środowisku informatycznym rachunkowości, Wydawnictwo Uniwersytetu Łódzkiego, Łódź. 
Iwaniuk W. (2010), Miażdżaca opinia o analizie UniCredit, „Parkiet”, numer z 7 stycznia 2010 r., www.parkiet.com/artykul/885034.html (data dostępu: 21 marca 2018).

Jegadeesh N., Titman S. (1995), Overreaction, delayed reaction, and contrarian profits, ,Review Of Financial Studies”, nr 8 (4), s. 973-993.

Jegadeesh N., Kim J., Krische S.D, Lee C.C. (2004), Analyzing the analysts: When do recommendations add value?, „Journal of Finance”, nr 59 (3), s. 1083-1124.

Kazimierczak A. (2009), Bioton - Adam Wilczega zapłaci 100 tys. zt kary, „Parkiet", nr z 25 marca 2009 r., www.parkiet.com/artykul/794500.html (data dostępu: 10 marca 2018).

Komisja Nadzoru Finansowego (2007), Komunikat z XII posiedzenia Komisji Nadzoru Finansowego w dniu 1 lutego 2007, www.knf.gov.pl/o_nas/komunikaty (data dostępu: 27 stycznia 2018).

Komisja Nadzoru Finansowego (2009), Decyzja Komisji Nadzoru Finansowego, Uchwała nr 63/2009 z dnia 24 marca 2009 r. w sprawie nałożenia kary pieniężnej na Adama Wilczęgę, https://bip.knf.gov.pl/pliki/dziennik_ nr_5_2009_12039_tcm6-12039.pdf (data dostępu: 27 stycznia 2018).

Komisja Nadzoru Finansowego (2011), Wzmocnienie ochrony uczestników rynku kapitałowego, Urząd Komisji Nadzoru Finansowego, Warszawa.

Komisja Nadzoru Finansowego (2018), Wykaz kar natożonych przez Komisje Nadzoru Finansowego, https://bip.knf.gov.pl/pliki/kary_KNF_16-01-2018 tcm6-27121.pdf (data dostępu: 27 stycznia 2018).

Krasodomska J. (2014), Informacje niefinansowe w sprawozdawczości spótek, Wydawnictwo Uniwersytetu Ekonomicznego w Krakowie, Kraków.

Langefors B. (1980), Infological models and information users view, „Information Systems", nr 5, s. 17-32.

Laudon K.C., Laudon J.P. (1991), Business information systems: A problem solving approach, Dryden Press, Chicago.

Lee J., Lee J.W. (2015), Analyst herding behavior and analyst affiliation: Evidence from business groups, „Journal of Behavioral Finance”, nr 16 (4), s. 373-386.

Lim T. (2001), Rationality and Analysts' Forecast Bias, „Journal of Finance”, nr 56, s. 369-385.

Lorie J.H., Dodd P., Kimpton M.H. (1985), The stock market: Theory and evidence, Dow-Jones-Irwin.

Łukasik G. (2013), Relacje inwestorskie spótek kapitałowych, Wydawnictwo Difin, Warszawa.

Martysz C.B. (2015), Manipulacje instrumentami finansowymi i insider trading. Analiza prawno-ekonomiczna, Wolters Kluwer Business, Warszawa.

Meyer B. (2006), Informacja w procesie obstugi ruchu turystycznego, „Ekonomiczne Problemy Turystyki”, nr 7, s. 225-229.

Mikołajek-Gocejna M. (2008), Otwartość informacyjna spótki jako źródto wzrostu jej wartości [w:] Szablewski A., Pniewski K., Bartoszewicz B. (red.), Value Based management. Koncepcja, narzędzia, przykłady, Poltext, Warszawa. 
Minsky H. (1982), Can 'it' happen again? Essays on instability and finance, M.E. Skarpe, New York.

Mullainathan S., Shleifer A. (2005), The market for news, „American Economic Review", nr 95 (4), s. 1031-1053.

Newell A., Simon H.A. (1972), Human problem solving, Prentice Hall, Englewoods Cliffs.

Oleński J. (2001), Ekonomika informacji, PWE, Warszawa.

Patterson R. (2010), Kompendium terminów z zakresu finansów po polsku i angielsku, Zielona Sowa, Kraków.

Pavio A. (1986), Mental representations. A dual coding approach, Oxford University Press, New York.

Pound J., Zeckhauser R.J. (1990), Clearly heard on the street: The effect of takeover rumors on stock prices, ,Journal of Business”, nr 63 (3), s. 291-308.

Probst G., Raub S., Romhardt K. (2004), Zarzadzanie wiedza w organizacji, Oficyna Ekonomiczna, Kraków.

Roguski A. (2006a), Kto pompuje kurs Polnej?, „Parkiet”, nr z 27 stycznia 2006 r., www.parkiet.com/artykul/429062.html (data dostępu: 21 kwietnia 2018).

Roguski A. (2006b), Sprawa ŻIF będzie wyjaśniona, „Parkiet”, nr z 30 stycznia 2006 r., http://biznes.interia.pl/gieldy/news/sprawa-zif-bedzie-wyjasniona,711854,1844 (data dostępu: 10 kwietnia 2018).

Rosnow R.L. (1991), Inside rumor: A personal journey, „American Psychologist", nr 46 (5), s. 484-496.

Rozporządzenie Parlamentu Europejskiego i Rady (UE) nr 596/2014 z dn. 16 kwietnia 2014 r. w sprawie nadużyć na rynku (rozporządzenie w sprawie nadużyć na rynku) oraz uchylające dyrektywę 2003/6/WE Parlamentu Europejskiego i Rady i dyrektywy Komisji 2003/124/WE, 2003/125/WE i 2004/72/WE.

Statystyka Policja (2019), Przestępstwa przeciwko obrotowi pieniędzmi i papierami wartościowymi (s. 310-316), http://statystyka.policja.pl/st/kodeks-karny/ przestepstwa-przeciwko-18/63905,Falszowanie-informacji-w-obrocie-papierami-wartosciowymi-art-311.html (data dostępu: 1 czerwca 2019).

Stefanowicz B. (2010), Informacja, Oficyna Wydawnicza SGH, Warszawa.

Stefanowicz B. (2013), Informacja, wiedza, madrość, GUS, Warszawa.

Stiglitz J.E. (2004), Ekonomia sektora publicznego, Wydawnictwo Naukowe PWN, Warszawa.

Stokłosa A., Syp S. (2017), MAR. Rozporzadzenie Parlamentu Europejskiego $i$ Rady w sprawie nadużyć na rynku. Komentarz, Wolters Kluwer, Warszawa.

Stowarzyszenie Inwestorów Indywidualnych (2016), Inwestorzy indywidualni na polskiej gietdzie, Wyniki Ogólnopolskiego Badania 2016, Warszawa, www.sii.org.pl/10487/edukacja-i-analizy/badania-i-rankingi/ogolnopolskiebadanie-inwestorow-obi-2016.html (data dostępu: 12 listopada 2017).

Sundgren B. (1973), An infological approach to data bases, Skriftserie Statistika Centralbyran, Stockholm. 
Szyszka A. (2009), Finanse behawioralne. Nowe podejście do inwestowania na rynku kapitałowym, Wydawnictwo Uniwersytetu Ekonomicznego w Poznaniu, Poznań.

Szyszka A. (2013), Bahavioral finance and capital market, Palgrave Macmillian, New York.

Tomczuk P., Gajda K. (2013), Od czego zależa rekomendacje analityków, „Harvard Business Review Polska”, nr 129, s. 125-130.

Tversky A., Kahneman D. (1983), Extension versus intuitive reasoning: The conjunction fallacy in probability judgment, „Psychological Review”, nr 90 (4), s. 293-315.

Uhl M.W. (2014), Reuters Sentiment and Stock Returns, „Journal of Behavioral Finance", nr 15 (4), s. 287-298.

Ursul A.D. (1971), Informacija, Nauka, Moskwa.

Ustawa z dnia 29 lipca 2005 r. o obrocie instrumentami finansowymi (Dz.U. z 2005 r. nr 183, poz. 1538).

Warneryd K.E. (2001), Stock-market psychology. How people value and trade stocks, Edward Elgar Publishing, Cheltenhan.

Wierzbicki T. (1981), System informacji gospodarczej, PWE, Warszawa.

Zatoński K. (2010), KNF zamyka sprawe kar za opcje walutowe, „Puls Biznesu”, nr z 29 czerwca 2010 r., www.pb.pl/knf-zamyka-sprawe-kar-za-opcje-walutowe-564189 (data dostępu: 20 stycznia 2018).

Zeleny M. (1987), Management support systems: Towards integrated knowledge management, „Human Systems Management”, nr 7 (1), s. 59-70.

Zielonka P. (2011), Giełda i psychologia. Behawioralne aspekty inwestowania na rynku papierów wartościowych, $\mathrm{CeDeWu}$, Warszawa.

\section{Streszczenie}

Celem artykułu jest opisanie i scharakteryzowanie zjawiska manipulacji cenami instrumentów finansowych za pomocą informacji. W pierwszej części pracy, na podstawie konceptualnej analizy literatury przedmiotu, przedstawiono pojęcia informacji i manipulacji w kontekście obowiązujących uregulowań prawnych oraz funkcji pełnionych na rynku finansowym. W drugiej części posłużono się danymi Komisji Nadzoru Finansowego do przeprowadzenia przyczynku do analizy znaczenia jakości informacji finansowej dla efektywności rynku w odniesieniu do najważniejszych źródeł komunikatów wykorzystywanych przez inwestorów: raportów okresowych i bieżących, analiz i rekomendacji analityków, doniesień medialnych czy informacji poufnych, plotek i pogłosek. Przedstawione zostały także konkretne przykłady manipulacji informacją na polskim rynku kapitałowym w latach 2006-2017.

Słowa kluczowe: informacja, manipulacja, rynek finansowy, Market Abuse Regulation (MAR) 


\section{Summary}

Market manipulation by disseminating false information: A contribution to the analysis on the basis of the capital market in Poland

The aim of the article is to describe and present the basic characteristics of the phenomenon of market manipulation made by disseminating false information. In the first part of the study, based on a conceptual analysis of the literature on the subject, the idea and functions of information and manipulation on financial markets are shown from the financial and legal point of view. In the second part, on the basis of the Polish Financial Supervision Authority's statistics, the importance of quality of information for the efficiency of financial markets is analyzed. The contribution to the analysis was conducted on a sample of the most important sources of announcements for investors: financial reports, analyses and recommendations, media reports and rumors. The examples of manipulations which took place between 2006 and 2017 in the capital market in Poland are also presented.

Keywords: information, manipulation, financial market, Market Abuse Regulation (MAR)

JEL: G14, G40 